\title{
ČAPKOVO „DESATERO PRO TYTO VELIKÉ DNY“ JAKO SPOLEČENSKÝ A POLITICKÝ MANIFEST KE ZRODU PRVNÍ REPUBLIKY V ROCE 1918
}

\author{
AGNIESZKA JANIEC-NYITRAI
}

JANIEC-NYITRAI, Agnieszka: Čapek's “Decalogue for These Great Days” as a Social and Political Manifesto to the Birth of the First Republic in 1918, 2019, Vol. 1, Issue 1, pp. 69 - 75. DOI: 10.17846/ CEV.2019.01.1.69-75.

ABSTRACT: The study is devoted to the analysis of Karel Čapek's article „Decalogue for these great days“. Čapek published his article on the day after the establishment of an independent Czechoslovakia, on the 29th of October, 1918. This text can be regarded as a manifesto of the emerging new state. Capek is essentially very rational and does not allow himself to be too enthusiastic on the first days of independence. The program he formulates is very definite and clear. Čapek's Decalogue carries a strong moral mission. All these aspects are analyzed in the study.

KEYWORDS: Karel Čapek. Journalism. Independent Czechoslovakia.

\section{1.ÚVOD}

Karla Čapka lze považovat za jednoho z duchovních otců první republiky. Jako jeden z předních spisovatelů se významně zasloužil o kulturní a společenský rozkvět československého státu, stal se kulturním velvyslancem Československa v zahraničí, „vývozním zbožím“ do ciziny a vizitkou reprezentující všechno, co je v české kultuře meziválečného období nejlepší. Jak je známo, byl v blízkém přátelském vztahu s prvním prezidentem Československé republiky Tomášem Garriguem Masarykem a je také autorem Hovorů s $T G M^{1}$, v nichž Masaryk komplexně vyložil své politické, sociální a kulturní myšlení. ${ }^{2}$ Čapek blízce spolupracovat mj. také s Edvardem Benešem (Olivová 2000, 11 - 57). Právě ve vile na Vinohradech, jejíž půlka patřila mladšímu z bratří Čapků, se scházeli pátečníci, neformální spolek českých intelektuálů - vědců, spisovatelů a politiků. Čapek hbitě reagoval na kulturní a politické otázky, které s sebou přinesl vznik první republiky, zúčastnil se mnoha polemik, často např. často nesouhlasil s významným českým katolickým spisovatelem Jaroslavem Durychem (Hora 2006, 196 - 201).

Čapka lze také považovat za jednoho z mluvčích mladého československého státu. V neposlední řadě právě on svými četnými publicistickými články podporoval československou státnost, reagoval na mezinárodní dění a v roce 1938, v době postupné dekonstrukce Československa, v emotivních novinářských př́spěvcích apeloval na uklidnění situace; své četné texty věnoval napr. i vztahům se sudetskými Němci. Čapek se od 30. let projevoval jako přesvědčený obránce demokracie a zastánce udržení geopolitického status quo, který nejen ve svých politicky zaměřených článcích, ale také v uměleckých dílech (především Válka s mloky, Bílá nemoc, Matka) bojoval proti stále silnějšímu fašismu. Osobně se snažil ovlivnit situaci v Československu, pokoušel se zmírnit napětí mezi národy a národnostními menšinami bydlícími na území Československa, kupř́íkladu v srpnu 1938 osobně jednal s Jánosem Esterházym, československým poslancem a vůdčí osobností mad’arské menšiny v době první republiky (Čapek 2005, 56). Čapek se stal symbolem hroutícího

\footnotetext{
O podstatném vlivu Hovorů s TGM na vývoj Čapkovy beletristické tvorby, hlavně noetické trilogie, píše Jiř́ Opelík v pozoruhodném článku „O skryté roli knihy Hovory s T. G. Masarykem“ (Opelík 2016, $21-37)$.

2 O vztazích mezi Masarykem a Čapkem viz. Houška 2011.
} 
se Československa a nakonec, v prosinci 1938, zdrcen mnichovskou dohodou a přesvědčen o konci světa, který sám spolutvořil, ve věku 48 let zemřel.

Čapek už následující den po vzniku samostatného Československa, 29. října 1918, v deníku Národní listy zveřejnil článek s výmluvným názvem Desatero pro tyto veliké dny (Čapek 1988, 77 - 78). Tento text lze považovat za jistý manifest rodícího se nového státu, v němž Čapek shrnul nejpodstatnější postuláty pro tyto, $\mathrm{z}$ hlediska vývoje velmi podstatné, první dny a měsíce svobody.

Cílem našeho článku bude analýza Čapkova svébytného politického, kulturního a společenského programu, jejž autor v „Desateru“ formuloval. Chtěli bychom také poukázat na př́nos tohoto textu v procesu formování českého myšlení týkajícího se kategorie svobodného, nezávislého státu. Na těchto deset bodů budeme nahlížet v kontextu Čapkova filozofického myšlení, s přihlédnutím na jiné Čapkovy publicistické texty zveřejněné na podzim a v zimě roku 1918 (např. článek Překřtění ulic publikovaný v časopise Cesta 8. listopadu 1918 nebo Několik otázek velké Prahy, zveřejněný 6. prosince 1918 také v Cestě), které jsou příkladem jisté praktické realizace Čapkových postulátů $\mathrm{z}$ „Desatera“. Prostor věnujeme také jazykově-stylistickému rozboru textů.

\section{2. ČAPKOVO „DESATERO“}

Prvním očividným rozdílem mezi biblickými deseti přikázáními a Čapkovou sekulární verzí je, že Čapek zvolil odlišnou komunikační perspektivu. S lidmi, jimž je jeho „Desatero“ určeno, autor nekomunikuje prostřednictvím imperativu vyjadřujícího negaci (jak je tomu ve většině starozákonních přikázání, např. „Nebudeš mít jiné bohy mimo mne. Nepokradeš“), ale používá „pozitivni““ rozkazovací způsob. Díky tomu má čtenář dojem, že se jedná o konsolidační program, zakládající se na pozitivním vyznění, že jde o jakési společně vypracované stanovisko, nikoli o něco vynuceného a omezujícího.

Deset přikázání nově se rodícího státu lze rozdělit podle obsahového a významového hlediska do čtyř podskupin zahrnujících 1) demokratický kontext, 2) úvahy o novém politickém systému a také 3) morální a 4) materiální dimenzi lidského působení v nově se formujícím státě. Podle tohoto třídění se prvních dvou témat týkají tři a tři „přikázáni“", následujícím dvěma podskupinám, jsou věnována vždy čtyři „přikázání“.

\section{1. DEMOKRATICKÝ KONTEXT}

Výzva $\mathrm{k}$ demokratizaci poměrů je výrazně př́tomna ve třech bodech Čapkova programu. Už ve druhém bodě Čapek trochu „podvratným“ způsobem postuluje smysl demokracie v současných pomèrech:

„II. Chopte se vlády; chopte se především vlády nad sebou samými; svobodný člověk není otrokem davu ani vášně (Čapek 1988, 77).

Jeho výzva k chopení se vlády neznamená touhu po získání moci nad ostatními, právě naopak: Čapek zdůrazňuje, jak podstatné je sebeovládání, vypořádává se s nízkými lidskými pudy, které vedou k přijetí moci nad slabšími. Opravdová svoboda podle Čapka znamená osvobození se od davového, primitivního myšlení, což podle něj stojí v protikladu k ideálům demokracie.

„VI. Nepovažujte se za pány nad druhým zemským kmenem; budou našimi rovnoprávnými spoluobčany. Každou nacionální urážkou, každým sebemenším př́kořím hřešite proti spravedlivému duchu míru Wilsonova" (ibid., 77).

V šestém bodě svého manifestu Čapek ukazuje, jak podstatné je spravedlivé a demokratické uspořádání nového státu, $v$ němž se ocitlo mnoho národnostních menšin. Je zde vidět jeho předvídavost. Rovnoprávnost je jedinou cestou $\mathrm{k}$ existenci Československa v nově zřízeném rámci. Český spisovatel se zde dovolává postulátů amerického prezidenta W. Wilsona, který v lednu 1918 
ve čtrnácti bodech formuloval nové zásady uspořádání Evropy a světa. Walter Schamschula zdůrazňuje vlastenecké vyznění textu, ale také Čapkův požadavek akceptace jiných národností žijících v nově vzniklém Československu (Schamschula 2004, 221). Co se týče budoucnosti české společnosti, Čapek reprezentoval jasná stanoviska: pouze vytvořením vskutku demokratické a občanské společnosti je možné položit trvalé základy mladého československého státu, v němž podstatnými budou duševní svoboda, respekt k jiným, vyspělá politická kultura a humanitní přístup ke světu a životu (Pfaff 1994, 125). Stabilita je možná pouze tehdy, když bude nový stát tolerantní a otevřený vưči všem občanům první republiky.

„IX. Použijte této doby $k$ sblížení. Odstraňte hranice tříd, stran a názorů, nikoli abyste hledali kompromis, nýbrž abyste hledali a našli vzájemné bratrství. Dnes, nebo nikdy musíte dojíti k národní solidaritě a jednotě. Vší silou, s nejupřímnějším srdcem hledte se sbližiti“ (Čapek 1988, 78).

Čapekvyzývá spoluobčanykhluboképroměně mezilidských vztahů. Všechnyhranicejsou podle Čapka něčím zlým, co lidi od sebe vzdaluje a nenávratně ničí mezilidské bratrství. Právě idea bratrství je nadřazenou hodnotou, nejde pouze o politický nebo názorový kompromis. Idea bratrství se váže k české evangelické církevní organizaci Jednota bratrská, v níž právě tyto ideály soužití zakládajícího se na vzájemné pomoci byly obzvlášt zdůrazněny. Právě ted', u zrodu nového státu, přichází moment, kdy by na prvním místě měla být solidarita a jednota. Mezi lidmi, kteří jsou zastánci odlišných stanovisek, mohou existovat rozdíly, ale tito lidé by neměli vystupovat z pozice lepšího a silnějšího, musí respektovat přesvědčení jiných a názorovou pestrost. Právě demokratické smýšlení bylo vizitkou Čapkova světonázoru, jak píše Ivan Pfaff: „[...] všechny silokřrivky a souřadnice Čapkovy politické orientace a jeho politické filozofie nakonec vždy mírí k demokracii“ (Pfaff 1994, 123).

\section{2. NOVÝ POLITICKÝ SYSTÉM}

„III. Budte poslušni naší národní vlády, našeho Národního výboru; budte poslušni výkonných orgánů, jež ona ustanoví. Jen vaše poslušnost vloži moc do rukou lidové české vlády“ (Čapek 1988, 77).

Nový politický systém je teprve ve stadiu zrodu. V dalších třech bodech svého memoranda Čapek motivuje československé spoluobčany, aby akceptovali rozhodnutí národní vlády. Podle Čapka je důležitá důvěra $v$ proud změn, důvěra ve smysl existence mladého státu.

Dále Čapek občany přesvědčuje, že změny, které jsou nutné, potřebují čas. Varuje před chaosem a zmatkem, který vzniká v důsledku lidské netrpělivosti. Češi musí věřit ve smysluplnost společné cesty i přesto, že jisté změny či reformy mohou být zaváděny pouze pomalu a postupně.

„VII. Budte trpěliví; nepujde, nemůže vše jíti hladce; přejímání těžkopádných aparátů bývalého státu zpưsobí mnohý průtah a mnohé tvrdé obtíže. Nereptejte, sečkejte; netrpělivost vede jen k nepoř́dku“ (ibid., 77).

Čapek ještě jednou zdůrazňuje podstatnou úlohu důvěry v mladou československou vládu, podotýká, že československá vláda jedná v souladu s politikou a přesvědčením československé vlády v zahraničí. Pouze společné, jednotné stanovisko bude garantovat trvalý mír a povede k vývoji celého státu.

„VIII. Důvěrujte! Duvěřrujte naší národní vládě, jež jedná ve shodě s českou vládou v zahraničí. Dưvěrujte mezinárodnímu mírovému dílu, jež urovná práva národní a lidská. Nežádejte řešení všeho už ode dneška. Naši bratři za hranicemi musejí spolurozhodovati s námi“ (ibid., 77).

Podle Čapka je také důležité jednotné stanovisko celé země v mezinárodní aréně, protože spory a sváry v lůně mladého státu poukazují na jeho slabost a rozkolísanost názorů. 
Agnieszka Janiec-Nyitrai

\section{3. MORÁLNÍ ROZMĚR}

Neméně důležitý je pro Čapka morální směr vývoje mladého Československa. Radost, která občany naplňuje, by měla být důstojná.

„I. Radujte se - to netřeba ř́kati; ale radujte se tak, aby radost vaše byla hodna tři set let čekání, aby vyvážila třistaleté utrpení vašich otcư, aby byla velikou a krásnou událostí našich dějin“ (ibid., 77).

Čapek je přesvědčen, že nový, silný stát může být vytvořen pouze na základě upřímné bratrské pomoci a solidarity. V posledním bodě svého poselství navazuje na těžké období první světové války, zdůrazňuje, že tato doba byla plná smutku a utrpení. Pouze ze srdce plynoucí potřeba pomoci svým bližním může vést k rozvoji nového státu.

„X. Vzájemná pomoc budiž největším př́kazem. At není hladových a vyděděných mezi námi, $v$ zemi české! At' láska učiní konec nesmírnému utrpení, jež zavinila válka i predválečný tvrdý, dnes překonaný život!“ (ibid., 78).

\section{4. MATERIÁLNÍ DIMENZE}

Pro Čapka má podstatný hmotný rozměr lidská práce jako cesta k zdokonalování poměrů v celé zemi. Čapek po lidech nechce velké činy, nechce hrdinství, nechce prázdná slova, ale podtrhuje význam systematické, každodenní práce, význam činu, význam námahy, která přispívá ke společnému obohacení celého státu. Význam má každý jednotlivý občan, všechno, i nejskromnější dílo lidských rukou, je obdařeno svým smyslem, je důležité pro ostatní. Pro Čapka je rozhodující lidská aktivita, vynalézavost, chut do práce.

„IV. At jakékoliv dílo vychází z vašich rukou, vratte se $k$ němu. Z každé nepřerušené práce plyne nekonečný užitek svobodné vlasti. Každá skutečná práce buduje život českého státu; jednou každou se účastníte vy osobně na jeho zajištěni" (ibid., 77).

„V. Šetřete majetku - šetřite tím majetku českého státu. Neničte ničeho. Každou rozbitou tabulkou ubiráte něco z majetku veřejného" (ibid., 77).

Čapek se snaží změnit lidský postoj ke společnému majetku. Všechno, co patří státu, je společné, tedy je tř̌eba si toho vážit. Národní majetek je majetkem všech, každého člověka, doba vlády Habsburků neodvratně skončila. Tento postulát je důležitý, má za cíl změnit vžité zvyky.

\section{DALŠÍ ČLÁNKY S PODOBNOU TEMATIKOU}

Článek Desatero pro tyto veliké dny obsahuje spíše obecná ponaučení a teoretická východiska Čapkova programu. Konkrétní výzvy, před nimiž stojí nový stát, najdeme v dalších článcích, které Čapek publikoval během několika měsíců od vzniku Československa. Nejpozoruhodnější jsou následující texty: Překřtění ulic, publikovaný v časopise Cesta 8. listopadu 1918, a Několik otázek velké Prahy ze 6. prosince 1918 (také časopis Cesta).

V prvním textu Čapek popisuje typický proces změny městského prostoru pod vlivem transformace politického režimu. Změna režimu vyžaduje změnu názvů ulic, náměstí, nádraží, parků. Tyto změny jsou přirozené a jsou důsledkem entuziasmu a radosti ze vzniku nového státu. Nicméně tyto procesy jsou podle Čapka chaotické a vyžadují podle něj přiměřenou míru opatrnosti a delší čas k uvažování.

„První hnutí ulice bylo: odstraniti vše, co připomínalo starý režim. Druhé hnutí bylo: pohnutka vděku a oslavy. Rázem vynořily se názvy Wilsonovo nádraží, Wilsonova třída, náměstí Republiky, Masarykova třída a podobné. Nuže, věřim až pověrečně, že každé lidové hnutí obsahuje kus hlubší pravdy. Písi-li dnes článek nesouhlasu, není to proto, abych se stavěl napříc onomu lidovému hnutí, 
nýbrž abych se pokusil naznačiti, že jest nutno se ho chopiti stejně ve velkém jako opatrně“ (Čapek 1988c, 79).

Čapek se staví proti divokému počeštování městského prostoru Prahy a nepromyšleným zásahům do tkáně města. Na jedné straně podporuje radikální proměnu pražských toponym, na druhé straně zdůrazňuje, jak důležité je plánování a zvážení budoucího růstu některých periferních čtvrtí. Pranýřuje opakování stále stejných názvů, což vede ke zmatku a k nepotřebnému chaosu. Pro Čapka má také důležitý význam tradice, proto odmítá úplnou změnu pražských toponym. „Odtud konkrétní požadavek: nejen šetriiti těchto starých, památných názvio, nýbrž obnoviti je všude, kde překřtívací nešetrnost minulých let je odstranila“ (ibid., 81). Čapek se jeví jako citlivý pozorovatel charakteru města. Změny názvů ulic a náměstí by měly probíhat v souladu s přirozenými vlastnostmi prostoru.

"Chcete-li oslaviti něči jméno, dbejte toho, aby nebylo jen prázdnou, libovolnou etiketou přibitou na nárožích, nýbrž aby bylo něčím více: duší ulice, di̛věrným, skoro osobním př́vlastkem místa" (ibid., 81). Politické a státotvorné důvody jsou sice důležité, ale je třeba především brát ohled na jiné aspekty.

Čapek se dělí se čtenáři o svou filozofii prostoru. Jeho hlas je vyrovnaný, klidný, apeluje na promyšlenou organizaci nově získaného města. Upozorňuje na to, jak velké škody může působit plýtvání jmény.

„Město není skladiště jmen. Je tu stejnè třeba soustavy jako rozmanitosti. Vinohrady jsou únavné jako slovník, Smíchov je neladný ve jménech jako inzertní stránka novin. Nomenklatura budoucí Prahy však budiž ř́zena kompozicí velkého slohu“ (ibid., 81).

Výměna toponym není pro Čapka pouze uvedení nových jmen, nejedná se o kosmetickou, povrchní změnu. Jde především o pravdu, která má pramenit $\mathrm{z}$ každého názvu.

„Pojmenování pražských ulic není jen práce verbální; jím má se spolutvořiti krajinný, organický a slavný ráz Prahy. A jako při každé tvorbě musí tu býti zákonem pravda, a nikoliv libovůle. Má-li býti Praha hodna jmen, jež bude nositi, musejí se tato jména státi něčím více než nárožními tabulkami. Chceme viděti Prahu vděčnou, ale chceme ji také viděti malebnou a krásnou i ve jménech, pravdivou a ladnou“ (ibid., 82).

Ve druhém článku, na nějž bychom chtěli upozornit, nazvaném Několik otázek velké Prahy, už Čapek řeší konkrétní výzvy, před nimiž stojí Praha jakožto bleskurychle se rozvíjející aglomerace. Čapek se jeví jako předvídavý hospodář, kterému nejsou cizí základní materiální otázky lidské existence ve velkoměstě. Vidí, že vzhledem k rychlému př́livu obyvatelstva do Prahy město ohrožuje bytová krize.

„Hlavní město republiky vyroste měrou nebývalou. Bude nutno vybudovati úřady, školy, ústavy a alespoň $v$ plánu musí se pamatovati na budoucí rozměry a potřeby kvetoucího národního života. Bude nutno odsunouti veliký průmysl za okraj města; vyhraditi veliké rozlohy pro komplex nemocniční, pro vilová města dělnická, pro sportovní stadion, pro sady. Avšak na prvním místě dlužno řešiti krizi bytovou" (Čapek 1988a, 86).

Další důležitou otázkou je vyřešení komunikačních těžkostí. „Každý moderní velkoměstský projekt je predevším projekt komunikační. Bez vydatné a krátké komunikace může vzniknouti kdekoliv jen ubohá periferní pustota" (ibid., 87).

Čapek vnímá politiku vývoje města $\mathrm{z}$ mnoha hledisek a ví, jaké důsledky může mít realizace nepromyšlených plánů. Autor nabízí konkrétní řešení a žádá techniky o ověření těchto myšlenek z hlediska inženýrského. Je zde vidět, že Čapkova koncepce vytváření nového státu se netýká pouze sfér filozofických a kulturních, ale zasahuje do konkrétních otázek společenského bytí. 


\section{ZÁVĚREM}

Čapkovo Desatero nese silné morální poslání. Má za cíl posílení vlasteneckého myšlení, ale také se zakládá na klasických českých ctnostech pěstovaných už od dob Jana Husa i Jana Ámose Komenského: pragmatismus, rozumový, věcný pohled na skutečnost, demokratické smýšlení, chvála skromnosti a malých krůčků, které vedou k cíli. „Desatero“ je napsáno jasným, srozumitelným jazykem. Čapek neadresuje svá slova intelektuálům, teprve se formující elitě nového státu, ale každému, komu je blízký osud Československa. Čapek se jeví jako demokrat, jako člověk respektující odlišnosti a bránící slabší.

Čapek je ve svých východiscích velmi střízlivý, věcný, nenechává se unést nadšením prvních dnů svobody. Program, který formuluje, je konkrétní. Je třeba zdůraznit, že je to dílo mladého, pouze osmadvacetiletého vlastence, který viděl hrůzy první světové války, který nikdy nežil v samostatném státě, který mnohokrát trpěl $\mathrm{z}$ důvodů zásahů cenzury, o čemž píše v hořkém článku O Herodesovi z 25. prosince 1918 (ibid., 93 - 94).

V dalších článcích $\mathrm{z}$ tohoto nesmírně živého a podnětného období vidíme Čapka jako neúmorného organizátora společenského života. Čapek na konkrétních příkladech z oblasti architektury a organizace městského prostoru prezentuje svá mínění o změnách, které se uskutečňují v prvních měsících samostatnosti, a nabízí určitá řešení, která mohou mít pozdější vliv na úroveň a komfort života obyvatel hlavního města. Čapek se jeví jako jedinec praktický, jemuž jsou blízké problémy „malého českého člověka“, jemuž záleží na rozvoji Československa v každé oblasti. Tvưrce, který se za pár let stane světoznámým díky svému dramatu $R U R$, se nevyhýbá řešení problémů každodenních, které mohly být pro ostatní malichernými a nepodstatnými. Čapek nemá strach kritizovat ani prezentovat své názory, je odvážný ve svých postřezích.

Četba těchto tř́ článků z posledních tř́i měsíců roku 1918 ukazuje Čapka jako člověka přemýšlivého, jako vlastence, který není lhostejný vưči změnám, jež nová situace přináší. A je vidět, že sám si vzal k srdci postuláty formulované v „Desateru“, že pouze systematická práce dává pozitivní výsledky. Všichni se musí zapojit do přestavby státu, nebot podstatou je solidarita a jednota. Je zřejmé, že se mladý spisovatel chce zapojit do politického a kulturního dění. Tento pozitivistický program byl pro Čapka směrodatným během celého meziválečného období - v prvním desetiletí prosperity i v krušných 30. letech. Demokratické ideály, úcta k druhému člověku, práce ve prospěch většiny, zvětšování státního hmotného a intelektuálního majetku zůstaly Čapkovi vždy blízké. Jeho stř̌́zlivý hlas často zazníval v těžkých momentech československé státnosti a byl vždy věrný tomu, co v říjnu roku 1918 jako 28-letý mladík formuloval v Národních listech.

\section{SUMMARY}

The study is devoted to the analysis of Karel Čapek's article Decalogue for these great days. Čapek published his article on the day after the establishment of an independent Czechoslovakia, on the 29 th of October, 1918. This text can be regarded as a manifesto of the emerging new state. Čapek is essentially very rational and does not allow himself to be too enthusiastic on the first days of independence. The program he formulates is very definite and clear. Čapek's Decalogue carries a strong moral mission. It is aimed at strengthening patriotic thinking, but it is also based on the classical Czech virtues cultivated since the times of Jan Hus and Comenius: pragmatism, an intellectual, factual view of reality, democratic thinking, esteem of modesty and small steps that lead to the goal. This text is written in simple, intelligible language. Čapek does not address his words only to the intellectuals, to the elite of the new state, but to anyone who cares about the fate of young Czechoslovakia. 


\section{LITERATURA}

Čapek, Karel, 1988. Desatero pro tyto veliké dny. In: K. Čapek, Od člověka k člověku I. Praha: Československý spisovatel.

Čapek, Karel, 1988a. Několik otázek velké Prahy. In: K. Čapek, Od člověka k člověku I. Praha: Československý spisovatel.

Čapek, Karel, 1988b. O Herodesovi. In: K. Čapek, Od člověka k člověku I. Praha: Československý spisovatel.

Čapek, Karel, 1988c. Překřtění ulic. In: K. Čapek, Od člověka k člověku I. Praha: Československý spisovatel.

Čapek, Karel, 2005. Tichý hlas. Praha: ARSCI.

Hora, Petr, 2006. K polemikám Karla Čapka s Jaroslavem Durychem. Uličný, O. (ed.) Opera Academiae Paedagogicae Liberecensis, Series Bohemistika. Liberec: Eurolitteraria \& Eurolingua.

Houška, Vítězslav, 2011. Karel Čapek a T. G. Masaryk. Karviná: Paris ve spolupráci s Masarykovým demokratickým hnutím.

Olivová, Věra, 2000. Spolupráce Karla Čapka s Eduardem Benešem. In: K. Čapek, O Eduardu Benešovi. Praha: Společnost Eduarda Beneše.

Opelík, Jiří, 2016. O skryté roli knihy Hovory s T. G. Masarykem. In: J. Opelík, Uklizený stůl aneb Moje druhá knižka o Karlu Čapkovi. Praha: Torst.

Pfaff, Ivan, 1994. O perspektivu lidského společenství. Politické myšlení Karla Čapka, Praha: Artfórum, Jazzová sekce.

Schamschula, Walter, 2004. Geschichte der tschechischen Literatur: Von der Grundung der Republik dis zur Gegenwart. Böhlau Verlag.

\section{KONTAKT}

Dr hab. PhDr. Agnieszka Janiec-Nyitrai, PhD.

Szláv és Balti Filológiai Intézet

ELTE BTK

Múzeum krt. 4/D

1088 Budapest

Mad’arsko

janiec.nyitrai@gmail.com 